\title{
TEACHERS' PERFORMANCE IN ONLINE LEARNING DURING COVID-19 OUTBREAK: AN ANALYSIS BASED ON 21st CENTURY PROFICIENCY
}

\author{
Daeng Ayub', M. Jaya Adi Putra² \\ 1,2 Graduate Program of Universitas Riau, Pekanbaru. \\ Corresponding author: daengayub@lecturer.unri.ac.id
}

\begin{abstract}
Article Info
Abstract

Received: 06 September 2021 The pandemic phenomenon has forced the world of education to change the Accepted: 25 October 2021 work pattern of services from conventional to online-based education and Published: 26 October 2021 learning services. This study aimed to describe and analyze the level of teachers' 21 st century proficiency and its effect on teachers' performance in online learning due to Covic-19. This research was conducted at the

\section{Keywords:}

Teachers; performance; 21 st century; online; learning.

Alkautsar Integrated Islamic Education Foundation School, with a population of 90 teachers and a sample of 68 teachers. This is a descriptive quantitative research conducted by a survey design. The main tool for data collection is a questionnaire. Data were analyzed using descriptive statistics by calculating the mean value of teachers' 21 st century competence and teachers' performance in online learning due to Covic-19. Inferential statistical analysis was also carried out to find the magnitude of the relationship and influence between variables. The results showed that the average score of level of teachers' performance in online learning was 3.56 in the high category. The 21 st century proficiency level of teachers with a mean value of 3.72 was also in the high category. It was also found that there is a significant relationship between 21 st century proficiency variables and teachers' performance in online learning of 0.809 . The effect of $21 \mathrm{st}$ century skills on teachers' performance in online learning was $65.50 \%$. The conclusion is that the better the 21 st century skills of teachers, the better the teacher's performance in online learning due to Covid-19.
\end{abstract}

\section{INTRODUCTION}

At the beginning of 2020, the world was shocked by the outbreak of a new virus, namely a new type of coronavirus (SARS-CoV-2), commonly called as Coronavirus disease 2019 (COVID-19). The Corona Virus (Covid-19) outbreak has created a variety of panics, including in the realm of education. As the virus has been a global threat, the 
delivery of education, in formal and informal activities, has radically shifted to online or network methods (Putri, 2020).

The pandemic has forced the world of education to change the work pattern of services from conventional to online-based education and online learning services. Online learning tsunamis have then occurred worldwide during the COVID-19 pandemic (Goldschmidt \& Msn, 2020). These changes have automatically put more burdens and challenges for teachers in the field.

As essential elements in teaching process, teachers and educators are required to undertake an unprecedented large-scale migration from traditional face-to-face education to online education or distance education (Bao, 2020; Basilaia \& Kvavadze, 2020). This is supported by technological developments that are not limited to the current 4.0 industrial revolution. Online learning is effective for implementing learning even though educators and students are in different places (Verawardina et al., 2020). According to Dewi (2020), this online learning can be a solution for teaching and learning process during pandemics.

Even though it is a pandemic, according to Pakpahan (2020) the learning process still can run well because of the rapidly developing information technology, including elearning, google class, whatsapp, zoom and other information media and internet networks that can connect teachers and students so that the teaching and learning process can run well as it should even in the midst of the COVID-19 corona virus pandemic. However, the success of this massive online learning much relies on the teachers' competencies.

It has been generally understood that a teacher is the main component of education which plays an important role in terms of planning, implementing and developing the curriculum. Therefore, being a professional teacher requires knowledge, skills, abilities, and expertise so he or she can support the students to achieve their educational goals and expectations.

The concept of modern education has emphasized that the teacher is a profession as formulated by Moh. Uzer (2010) and Abdul Majid (2012), that teacher is a profession. It means a position or job that requires special skills, with special conditions as well. A professional teacher is the one who can survive in serving the students at any situation, inculding the hard time like in this pandemics.

Professional educators should be able to do their roles and responsibilities, such as planning and implementing the learning process, conducting guidance and training, and conducting research and community service, especially for educators at higher education (Martinis Yamin, 2007). They should be able to deal with any challenges that might appear, including the challenges of online learning and the changes due to $21 \mathrm{st}$ century. 
The need to face the challenges of the 21 st century has led many countries to reform the curriculum with the aim of preparing students for higher education needs and jobs in the 21st century (Darling-Hammond, L. 2012). The teachers' challenges in the 21 st century is not easy and rather it is getting more difficult and the task of a teacher is not the simple one that happened in the past, but rather complex. So the heavier and more complex challenges can only be overcome with a performance, so performance must be continuously improved.

Susanto (2010), and Yahya (2010) describe the challenges that teachers must face in the 21 st century, namely 1) education that focuses on character building, 2) education that cares about climate change, 3) entrepreneurial minset, 4) building learning community , $5)$ competitive power is not in intelligence but in creativity and intelligence to act. The above challenges must be addressed properly with self-readiness and using appropriate methods, and different from the strategies or concepts that have been applied before, if the strategy is implemented incorrectly, the changes made will be disastrous for future generations.

Conceptually, teachers have adequate abilities in carrying out their duties and obligations professionally, but the real reality in the field is still concerning both in quantity and quality and this is another challenge for teachers in the era of globalization and teachers are able to deal with it and besides that teachers have characteristics, skills, skills, and the role of teachers in the 21st century (Daeng, 2020). Furthermore, Daeng \& M. Jaya (2019) state that teachers in the 21st century have the challenge of accelerating the development of information and communication. Class learning and classroom management must be adjusted to the standards of progress in Information and Technology development.

Trilling and Fadel (2009) and Wagner (2010) state seven skills needed in the 21st century, namely (1) critical thinking and problem solving skills, (2) collaboration and leadership, (3) agility and adaptability, (4) initiative and entrepreneurial spirit, (5) able to communicate effectively both orally and in writing, (6) able to access and analyze information, and (7) have curiosity and imagination. Barry (2012) and Frydenberg \& Andone (2011) state that the 21st century demands education to prepare students who are able to face global economic competition. Partnership for 21 st Century Skills emphasizes that $21 \mathrm{st}$ century learning must teach 4 competencies, namely communication, collaboration, critical thinking, and creativity.

Three are three concepts of 21 st century education that have been adapted by the Ministry of Education and Culture of the Republic of Indonesia: 21st century skills (Trilling and Fadel, 2009), scientific approach (Dyer, et al., 2009) and authentic learning and authentic assessment (Wiggins and McTighe, 2011; Ormiston, 2011; Aitken and Pungur, 1996; Costa and Kallick, 1992; and Anderson \& Karthwohl, 2010). Teachers should have broader knowledge related to information and technology, so the world of education must also change and orientation is no longer educational concepts of the past or present but must think ahead with a focus on how to put the ability to cope individually coupled with speed efficiently in adapting to changes that occur 
continuously, which includes 21st century skills. Trilling and Fadel (2009) mention some necessary 21 st century skills, namely: (1) critical thinking and problem solving; (2) creativity and innovation: (3) communication; and (4) collaboration.

The success of a teacher can be seen if the existing criteria have been achieved as a whole. If the criteria have been achieved, it means that a person's work is considered to have good quality work, because teachers' performance is the result of work that can be seen from a series of abilities possessed by a teacher (Daeng, 2019).

According to Hamzah \& Nina (2014), Priansa (2018), Daeng (2019), and Uzer (2010), teachers' performance in learning can be assessed from the following aspects: (1) designing lesson plans; (2) carry out the learning process; (3) carry out a learning evaluation; (4) personal relationships with students; and (5) develop their profession.

To be more specific, this study examined the teachers' performance in conducting online learning. According to Budi Murtiyasa (2012) and Rusman (2012), online learning is a learning activity process that involves various components, namely teachers, students, objectives, materials, methods, media, evaluation with education and learning resources in a learning circle to achieve goals. Online learning (E-Learning) includes delivering material as well as civilizing students to look for learning references online more widely and independently.

Horton (2003) and Riyana (2007) define online learning as all learning activities that use of internet and web technology to create learning experiences. Rusman (2011) explains that online learning can be seen as an innovative approach to be used as a media design for delivering good learning, user-centered, interactive and as a learning environment that has various conveniences for anyone, anywhere and anytime. Munir (2009) states that online learning is utilizing various attributes and sources of digital technology with other forms of learning materials and materials that are suitable for application in an open, flexible and distributed learning environment.

During covid-19 outbreak, the Indonesian government has obliged all schools to run the learning process from home to provide meaningful learning through online or distance learning (Mendikbud, 2020). Therefore, being a teacher during pandemic is currently getting more challenging, not only because teachers have to switch massively to online learning durung pandemic situations, but also because of gap in schools' quality accross regions in Indonesia. In some schools in Indonesia it is customary to apply online learning methods, but on the other hand there are also schools that are doing online learning for the first time. In online learning systems, there are several obstacles that are deemed ineffective, such as the provision of learning materials by teachers, technological literacy from teachers and parents who will guide children, and the economic condition of the child's parents (Muhdi \& Nurkolis, 2021). This study aimed to investigate how the teachers perform their duties during the online learning due to Covid19 outbreak. 


\section{METHODOLOGY}

This study aimed to describe and analyze the level of 21 st century proficiency and its effect on teachers' performance in online learning due to Covic-19. This research was conducted at the Alkautsar Integrated Islamic Education Foundation School, with the teacher as the subject.

This research is a descriptive quantitative research conducted by a survey. The study population was 90 teachers and the research sample was 68 teachers who teach the lowest level students to the highest level.

Data were collected using a questionnaire and analyzed using descriptive statistics to find the level of 21st century teachers' proficiency and teachers' performance in online learning due to Covic-19 by looking for the mean score of each indicator. Then, inferential statistical analysis was carried out to find the magnitude of the relationship and the influence between variables.

\section{RESULTS AND DISCUSSION}

\section{Research results}

The results of this study found that the level of teachers' proficiency of the 21 st century proficieny was classified as high, with a mean value of 3.72, as shown in the Table 1 below:

Table 1. Mean scores of 21st century teachers' proficiency levels based on indicators

\begin{tabular}{llll}
\hline No & Indicators & Mean & Interpretation \\
\hline 1 & Critical thinking and problem & 3.62 & High \\
& solving skill & & \\
2 & Communication skill & 3.34 & High \\
3 & Creativity and innovation & 4.00 & High \\
& & & \\
4 & Collaboration & 3.92 & High \\
\hline Average & 3.72 & High \\
\hline
\end{tabular}

Table. 1 explains that based on each indicator, creativity and innovation have the highest mean value of 4.00 followed by collaboration with a mean of 3.92. Furthermore, critical thinking and problem solving skills have a mean value of 3.62, and the lowest is communication with a mean of 3.34. This finding means that all 21 st century teachers' proficiency indicators are included in the high interpretation, but still need to be 
improved, because there are still 1.28 of the average total value of 3.72 out of a total of 5.00 which is determined by other indicators that are not part of this research.

Table 2. The mean value of teachers' performance level in online learning due to Covid-19 based on indicators

\begin{tabular}{llll}
\hline & Teachers' performance in online learning & & \\
No & due to Covid-19 & Mean & Interpretation \\
\hline 1 & Designing lesson plans & 3.63 & High \\
2 & Carrying out the learning process & 3.44 & High \\
3 & Carrying out a learning evaluation & 3.38 & High \\
4 & Maintaining personal relationship with & 3.91 & High \\
5 & students & 3.42 & High \\
\hline Average & 3.56 & High \\
\hline
\end{tabular}

Table 2 shows that there are five indicators of teachers' performance in online learning due to Covid-19 with a mean of 3.56 being in the high category. Based on each indicator, the indicator that has the highest mean value is a personal relationship with students with a value obtained of 3.91, then followed by designing a lesson plan with a mean value of 3.63, then carrying out the learning process with a mean of 3.44. Next, the indicator of developing the profession with a mean of 3.42 and the lowest indicator is implementing a learning evaluation with a mean of 3.38. This means that all indicators are included in the high category, but still need to be improved, because there are still 1.44 out of the total of 5.00 determined by other indicators.

Table 3. Pearson Product Moment Correlation Test Between 21st century proficiency and teachers' performance in online learning

\begin{tabular}{llll}
\hline Variable & $\mathrm{n}$ & $\begin{array}{l}\text { Pearson } \\
\text { Correlation }\end{array}$ & $\operatorname{Sig}(2-$ Tailed $)$ \\
\hline $\mathrm{X}-\mathrm{Y}$ & 68 & 0.809 & 0.001 \\
\hline
\end{tabular}

Table 3 depicts that the Pearson correlation test between 21 st century proficiency and teachers' performance in online learning due to Covid-19 obtained a Pearson correlation of 0.809 . This finding indicates that there is a significant relationship between $21 \mathrm{st}$ century skills and teachers' performance in online learning due to Covid-19. The relationship is quite strong between 21st century skills and teachers' performance, with a $\mathrm{P}$ value / Sig of $0.001<0.005$, so it can be concluded that there is a significant relationship between the two variables. 
Table 4. Model Summary of 21st Century Skills on Teachers' Performance in online learning due to Covid-19

\begin{tabular}{llll}
\hline $\mathrm{R}$ & $\mathrm{R} 2$ & Influence (\%) & Tafsiran \\
\hline 0.809 & 0.655 & $65.50 \%$ & High \\
\hline
\end{tabular}

Predictors: (Constant), 21st Century Skills

Dependent Variable: Teachers' performance in online learning due to Covid-19

Table 4 shows that the correlation between 21 st century skills and teachers' performance in online learning due to Covid-19 is 0.809. If seen from the product moment $\mathrm{r}$ table, at $\mathrm{n}=68$ with an error of $5 \%$ it is 0.240 , it means that the Pearson correlation or rcount $0.809>\mathrm{r}$ table 0.240 . Based on this correlation value, it is also known that the value of the coefficient of determination (R2) between teachers' performance in online learning in online learning due to Covid-19 at the Alkautsar Duri Integrated Islamic Education Foundation, Bengkalis Regency is 0.655 or $=65.50 \%$ which can be categorized as high. There are still $34.50 \%$ caused by other factors that are not part of this research. This influence means that the skills of the 21 st century on teachers' performance in online learning due to Covid-19 are already high. This means that the higher the 21 st century skills of a teacher, the higher the teacher's performance in online learning due to Covid-19.

\section{DISCUSSION}

The finding shows that teachers' performance in online learning during Covid-19 outbrea has a mean of 3.56 with a high interpretation. It can be understood that the performance of teachers in online learning due to Covid-19 has a relatively high level. Nevertheless, the teachers' performance in online learning should be still improved.

Tecahers' continous improvement is very important as they determine the success of the implementation of the learning activities carried out. As Hamzah \& Nina (2014), (Daeng, 2020) and Priansa (2018) explain that teachers are the main component of education which plays an important role in terms of planning, implementing and developing the curriculum. Therefore, a teacher must participate actively and place his position as a professional, in accordance with the demands of an increasingly developing society. In principle, the teacher has a high enough potential to be creative in order to improve his performance as a teacher.

Daeng and M. Jaya (2019) and Uzer (2010) mention that professional performance can continue to be improved if the welfare of teachers can be continuosly improved. Teachers' performance in online learning due to Covid-19 which is effective and efficient will produce strong human resources, namely graduates who are efficient and effective in accordance with the stated goals. As explained by Daeng (2019), Horton (2003), and Rusman (2013), a good quality education is greatly influenced by teachers' 
performance in online learning in carrying out their duties so that teachers' performance in online learning is an important requirement for achieving educational success.

In today's online learning, teachers are required to improve their performance because the learning process is carried out by following the developments in the 21 st century where at this time the development of science and technology will continue to develop. Based on research conducted by Kuntari Eri Murti (2015) education is now in the knowledge age with an extraordinary increase in knowledge. In this 21 st century, education is becoming increasingly important to ensure that students have the skills to learn and innovate, the skills to use technology and information media, and be able to work, and survive using life skills.

This studu also found that teachers' 21 st century proficiency has a mean of 3.72 with a high interpretation. Even though it is already in the high category, the skills of the $21 \mathrm{st}$ century still need to be improved. The findings in this study are similar to research conducted by Finita Dewi (2015). She emphasises that learning models that can improve critical thinking, collaborating, communicating and creative thinking skills are needed in the 21 st century education era. Collaboration with good friends in one group is necessary as well as with other groups both face-to-face and virtually, work and share responsibilities in completing digital book projects, then understand, respect opinions, listen to, and compromise with friends in making decisions, and communicate their ideas.

This 21 st century skill relates to various types of disciplines and many aspects of life (Wagner, 2010). These 21st century skills have no special place in the curriculum. According to Barry (2012) and Frydenberg \& Andone (2011), 21st century education involves aspects of skills and understanding, but also emphasizes aspects of creativity, collaboration and speaking skills. Some also involve technology, behavior and moral values, but they also emphasize critical thinking and communication skills which provide more challenges in the learning process than memorization and remote learning (P21, 2006).

The 21st century skills that are applied in online learning will greatly affect everyone, especially teachers and students, in this case the teacher is required to know more about and follow the times that are happening continuously. At this time teachers and students are required to have the ability to use technology in every learning process. 21st century skills challenge teachers and students to accelerate the development of information and communication. Classroom learning and management must be adapted to current developments.

Based on data of the product moment correlation, it was found that there is a significant relationship between 21 st century skills and teachers' performance in online learning during Covid-19, as indicated by 0.809 . The relationship is quite strong, with a $\mathrm{P}$ value $/$ Sig of $0.001<0.005$, so it can be concluded that there is a significant relationship between the two variables. 
The effect of 21 st century skills on teachers' performance in online learning due to Covid-19 is high at $65.50 \%$. However, there are still $34.50 \%$ who are not part of this research. This finding is in line with the research conducted by Sudirman and Agus Hakri Bokingo (2017). They argue that it is necessary to improve the quality of national education, in this case teachers as the foundation for the quality of national education. Teachers' performance in online learning can improve the quality of education, and with the quality of national education it can improve the quality of human resources. By improving the quality of human resources, Indonesia coud improve the quality of competitiveness in the 21 st century.

Based on research conducted by Rancak Lince (2016), the development of science, technology, arts and culture is increasingly advanced and rapid, requiring every teacher to be able to master and use it in order to expand or deepen learning material, and to support learning, such as the use of technology. information and communication. This increasingly advanced development encourages changes in the needs of students and society. This increasing need has triggered the increasing number of demands of students that must be met in order to win the competition in society.

Besides, teachers also have certain characteristics as distinguishing characteristics of teachers before the 21 st century and also have skills that also determine the quality of national education. Teachers' performance in online learning in the development of $21 \mathrm{st}$ century education has heavier challenges and more complex tasks. It is also very important for teachers to be able to manage the learning process. To face these challenges, teachers must have the ability (1) to think critically, (2) ) have a sense of social responsibility, (3) have the ability to build networks, (4) apply discipline in time and rules. In addition, teachers must have the characteristics, skills, skills of the $21 \mathrm{st}$ century.

According to Dewi (2020), teachers are required to play a role in increasing their ability to carry out innovations in learning that are in accordance with current developments. Pakpahan (2020) argued that teachers are expected to be able to take advantage of the media that continues to develop in learning. It is hoped that online learning does not break the spirit of teachers to continue to improve their performance, in today's online learning at least teachers will be literate about technology that will continue to happen.

So it can be concluded that 21 st century skills are very influential on teachers' performance in online learning in online learning due to Covid-19. Teachers must have the capability of 21 st century skills to be able to improve their performance and know the technology / media developments that continue to occur, especially during Covid19 , because if teachers do not have the skills of 21 st century skills, their performance will not increase and will interfere with the learning process. that's been done online at this point.

Verawardina (2020) states that a teacher has the task of guiding, directing and also being a good role model for their students, therefore, with a pile of duties and 
responsibilities that the teacher is able to show that the teacher is able to produce good performance for the creation of quality education in 21 st century skills that carry out the learning process using technology or media that are increasingly developing and will continue to develop. Teachers must be sensitive to increasingly sophisticated developments from time to time. Teachers should be creative in the online learning process; teachers can communicate well; they should have the ability to identify problems in online learning, because teachers have good social responsibility to their fellow teachers, to sthe tudents, even to the community. This online active learning will run well, if it is supported by the right strategy used by the teacher.

\section{CONCLUSION}

This study found that the mean value of teachers' performance level in online learning is 3.56 with a high category. The teacher's performance was determined by several indicators: (1) designing lesson plans; (2) carry out the learning process; (3) carry out a learning evaluation; (4) personal relationships with students; and (5) developing their profession. Furthermore, 21st century proficiency levels were obtained for teachers with a mean score of 3.72 in the high category, which was measured by indicators, namely: (1) critical thinking and problem solving; (2) creativity and innovation: (3) communication; and (4) collaboration.

It was also found that there is a significant relationship between 21st century proficiency variables with teachers' performance in online learning of 0.809 . In the development of 21 st century education, teachers are faced with challenges, therefore they must have the ability to think critically, have skills in communication, have skills in innovation and creativity and have the ability to collaborate. Furthermore, the effect of 21 st century skills on teachers' performance in online learning is $65.50 \%$ which is classified as high.

The performance of a teacher can not only be seen from how he is able to master the learning material, master the situation and master the situation of students. The performance of a teacher can also be seen from the ability of a teacher to take advantage of developments in science and technology. The more advanced developments will encourage the changes that occur. In online learning, teachers are required to have the skills of Abda 21 to continue to actively develop their abilities so that active learning will be realized in the online learning process due to Covid-19.

The findings imply that school principals need to improve the 21st century skills of teachers, especially those related to critical thinking skills, problem solving abilities, communication skills, innovation and creativity, and collaboration skills. The related parties to the management of school institutions also need to improve teachers' performance related to lesson planning, implementing the learning process, conducting the evaluation process, having personal relationships with students and being able to develop their profession. 


\section{ACKNOWLEDGMENTS}

We would like to thank the Director of the Riau University Graduate Program, Pekanbaru, Indonesia who has sponsored this research project through the research Grant No. 900 / UN19.5.1.03 / 2020, dated 05 June 2020.

\section{REFERENCES}

Abdul, Majid. (2012). Perencanaan Pembelajaran. Bandung: Rosda Karya

Ahmad Susanto. (2010). Teori Belajar Dan Pembelajaran. Jakarta: Raja Grafindo Persada.

Aitken, N \& Pungur, L. (1996). Authentic Assessment. [Online]. Diakses dari http://www.ntu.edu.vn/Portals/96/Tu_lieu\%20tham\%20khao/Phuong\% 20phap\%20danh\%20gia/authentic\%20assessment\%202.pdf

Anderson, L.W. dan Krathwohl, D.R. (2001). A Taxonomy for Learning, Teaching, and Asessing: A Revision of Bloom's Taxonomy of Educational Objectives. A Bridged Edition. New York: Addison Wesley Longman, Inc.

Bao, W. (2020). COVID-19 and online teaching in higher education : A case study of Peking University. March, 113-115. https://doi. org/10. 1002/hbe2.191.

Barry, M. (2012). What skills will you need to succeed in the future? Phoenix Forward (online). Tempe, AZ, University of Phoenix.

Basilaia, G., \& Kvavadze, D. (2020). Transition to Online Education in Schools during a SARS-CoV-2 Coronavirus (COVID-19) Pandemic in Georgia. Pedagogical Research, 5(4). https://doi.org/10.29333/pr/7937

Budi Murtiyasa. (2012). Pemanfaatan Teknologi Informasi dan Komunikasi Untuk Meningkatkan Kualitas Pembelajaran Matematika. Surakarta : FKIP Univ. Muhammadiyah Surakarta.[On-Line].Tersedia: http://physicsmaster. orgfree.com/Artikel-Jurnal\%20Dalam\%20Pendi dikan/TIKEduMath.pdf.

Costa dan Kallick. (1992). Belajar dan memimpin dengan "Kebiasaan pikiran". Jakarta : Indeks.

Daeng Ayub dan M. Jaya Adi Putra. (2019). Kesiapan Menghadapi Revolusi Industri 4.0 berdasarkan Optimalisasi Penggunaan Sarana Prasarana Pendidikan di Universitas Riau. Pekanbaru: LPPM Unri. 
Daeng Ayub Natuna. (2019). Perangai Guru Profesional: Meniti Gelombang Revolusi Industri 4.0 Menuju Society 5.0. Dalam Perangai Guru Profesional: GlobalisasiAbad 21-Revolusi Industri 4.0-Society 5.0. Pekanbaru: UR Press.

Daeng Ayub Natuna. (2020). Kepala Sekolah Abad 21. Pekanbaru. UR Press.

Daeng Ayub Natuna. (2020). Kompetensi Abad 21 Guru Profesional. Dalam Kepala Sekolah Abad 21. Pekanbaru. UR Press.

Daeng Ayub Natuna. 2018. The Contribution of Teachers' Accountability in Implementation of Learning Toward Implementation of Entrepreneurship Values. Proceeding of The 1st UR International Conference on Educational Sciences. ISBN : 978-979-792-774-5. P.322-329. 22 Januari 2018.

Darling-Hammond, L. (2012). Powerful Teacher Education: Lessons From Examplary Programs. USA: John Wiley \& Sons.

Dewi, Wahyu Aji Fatma. (2020). Dampak COVID-19 terhadap Implementasi Pembelajaran Daring di Sekolah Dasar. Edukatif : Jurnal Ilmu Pendidikan Volume 2 Nomor 1 April 2020 Halm 55-61.

Dyer, D. (2009). Alcohol-Free Instant Hand Sanitizer Reduces Elementary School Illnes Absebteeism; Clinical Research and Methods, 32(9),633-8.

Finita Dewi (2015) Proyek Buku Digital: Upaya Peningkatan Keterampilan Abad 21 Calon Guru Sekolah Dasar Melalui Model Pembelajaran Berbasis Proyek. Metodik Didaktik: Jurnal Pendidikan Ke-SD-An 9 (2) Vol. 9, No. 2, Januari 2015. Universitas Pendidikan Indonesia Kampus Purwakarta

Frydenberg, M., \& Andone, D. (2011). Learning for 21 st Century Skills, 314-318.

Hamzah \& Nina (2014). Teori Kinerja dan pengukuranya. Jakarta: Bumi Aksara.

Horton, William \& Horton, Katherine. (2003). E-Learning Tools and Technologies: A consumer guide for trainers, teachers, educators, and instructional designers. USA : Wiley Publishing, Inc.

Kuntari Eri Murti (2015). Pendidikan Abad 21 dan Implementasinya Pada Pembelajaran di Sekolah Menengah Kejuruan (SMK) untuk Paket Keahlian Desain Interior. (Online). (Diakses 20 November 2014).

Martinis Yamin. (2007). Profesionalisasi Guru \& Implementasi KTSP. Jakarta: Gaung Persada Press.

Mendikbud. (2020). Surat Edaran Pelaksanaan Kebijakan Pendidikan dalam Masa Darurat Penyebaran Covid-19. Jakarta: Depdikbud

Muhdi \& Nurkolis. (2021). Manajemen Pendidikan.Yogyakarta: Pustaka Pelajar 
Munir. (2009). Pembelajaran Jarak Jauh Berbasis Teknologi Informasi dan. Komunikasi. Bandung: Alfabeta.

Ormiston. (2011). Ormiston, Margaret E. Wong, Elaine M., dan Philip E. Tetlock. "Efek dari kompleksitas integratif tim manajemen puncak dan pengambilan keputusan yang terdesentralisasi pada kinerja sosial perusahaan." Jurnal Akademi Manajemen 54.6 (2011): 1207-1228.

P21 Partnership for 21st Century Learning. (2006). What We Know About Communication. Part of the 4Cs Research Series. US.

Pakpahan, A. K. (2020). COVID-19 dan Implikasi Bagi Usaha Mikro, Kecil, dan Menengah. 20 (April). DOI: https://doi.org/10.26593/jihi.v0i0.3870.59-64

Priansa. (2018). Perencanaan \& Pengembangan SDM. Bandung. Alfabeta.

Putri, R. E. (2020). Evaluation of the Efectiveness Online Class on Fudamental Biophysics Class During COVID 19 Quarantine. SEMESTA: Journal of Science Education and Teaching, 3(1), 65-70

Rancak Lince. (2016). Strategi Peningkatan Profesionalisme Guru Dalam Menghadapi Tantangan Di Era Digital. Universitas Terbuka Convention Center, 26 November 2016.

Riyana, Cheppy. (2007). Pedoman Pengembangan Media Video. Bandung:Program P3AI Universitas Pendidikan Indonesia.

Rusman. (2012). Model-Model Pembelajaran. Depok : PT Rajagrafindo Persada.

Rusman. (2013). Metode-Metode Pembelajaran: Mengembangkan. Profesionalisme Guru. Jakarta: PT RajaGrafindo Persada.

Sudirman \& Agus Hakri Bokingo. (2017). Kinerja Guru Pasca Sertifikasi. Perspektif Ilmu Pendidikan-Vol.31 No. 2 Oktober 2017. DOI: https:// doi.org/10.21009/PIP.312.5.

Verawardina, U., Asnur, L., Lubis, A. L., \& Hendriyani, Y. (2020). Reviewing Online Learning Facing the Covid-19 Outbreak. 12(3), 385-392.

Wagner. (2009). Gaya Hidup Shopping Mall sebagai Bentuk Perilaku Konsumtif Pada Remaja Di Perkotaan (Studi Kasus pada Konsumen Remaja di Tiga One Stop Shopping Mall di Jakarta). Bogor: Departemen Sains Komunikasi dan Pengembangan Masyarakat. Fakultas Ekologi Manusia IPB.

WHO (2020). WHO Information Note : Tuberculosis and COVID-19. 4 April 2020. Available from : https://www.who.int/ tb/COVID-19considerations-tuberculosis _services.pdf. 
WHO. (2020). World Health Organization. Clinical management of severe acute respiratory infection (SARI) when COVID-19 disease is suspected.Interim Guidance, 13 March 2020.

Wiggins, G. and McTighe, J. (2005). Understanding by Design. Alexandria: ACSD.

Yahya, A.F. (2010). Menaklukkan Pembunuh no.l : Mencegah dan Mengatasi Penyakit Jantung Koroner Secara Tepat. PT Mizan Pustaka, Bandung. 